\title{
STYLISTIC FEATURES OF NIKE SPORT SHOES PRODUCT SLOGANS ON ONLINE ADVERTISING
}

\author{
Julio Bois, Arry Purnama and Hartono.
}

English Department, Faculty of Letters, Al-Ghifari University, J1. A.H. NasutionSukamiskin no.247, Bandung, 40293, Indonesia

\section{Misterighoul@gmail.com}

\begin{abstract}
Abstrak: Dalam penelitian ini, peneliti menganalisis fitur gaya dari slogan produk sepatu olahraga Nike pada iklan online. Analisis fitur gaya berhubungan dengan penggunaan gaya bahasa. Bahasa adalah aspek mendasar dari kehidupan manusia. Bahasa adalah bagian penting dalam periklanan. Bahasa dalam iklan ditandai oleh slogan yang ada di setiap iklan. Ada banyak sekali slogan produk yang mengiklankan salah satunya slogan di bidang olahraga. Olahraga dan atletik adalah fenomena yang sangat dominan dalam masyarakat saat ini, seperti dalam slogan Olahraga memberikan inspirasi, identitas, dan motivasi. Peneliti menggunakan 27 slogan sebagai objek penelitian yang dianalisis dengan teori stilistik dari Lethsalu, Galperin dan teori slogan sebagai teori pendukung. Peneliti menganalisis fitur gaya berdasarkan bahasa linguistik dan mengambil tiga bidang linguistik, mereka adalah morfologi, Sintaksis, dan semantik. Penelitian ini menggunakan pendekatan deskriptif kualitatif. Ada beberapa langkah dalam menganalisis penelitian ini. Untuk mengetahui macam-macam fitur gaya yang digunakan dalam slogan produk sepatu olahraga Nike dan kemudian menjelaskan pesan slogan produk sepatu olahraga Nike di fitur gaya. Temuan analisis adalah sebagai berikut; fitur gaya yang digunakan di dalam slogan produk sepatu olahraga Nike adalah morfologi sebanyak 4 slogan, sintaksis dan semantik sebanyak 27 slogan. Pesan dari slogan produk sepatu olahraga Nike dalam fitur gaya adalah bahwa produk sepatu olahraga Nike memiliki kualitas dan kemampuan yang lebih baik dibandingkan dengan sepatu olahraga lainnya.
\end{abstract}

Kata kunci: Fitur-fitur gaya, slogan produk sepatu olahraga Nike. 


\begin{abstract}
Abstract: In this Research, the researcher analyzed stylistic features of Nike sport shoes product slogan on online advertising. Stylistic features analysis relates to using of language style. Language is a fundamental aspect of human life. Language is the important part in advertising. Language in advertising is typified by a slogan which is present in every advertisement. There are so many slogan products that in advertising one of his slogans in the field of sports. Sports and athletics are extremely predominant phenomena in today's society, as in Sports slogan provide inspiration, identity, and motivation. The researcher used 27 slogan as the object of the research which is analyzed by the theory of stylistic from Lethsalu, Galperin and theory of slogan as supporting theory. The researcher analyzed the stylistic features based on the linguistic filed and took three fields of linguistics; those are morphology, Syntax, and semantics. This research used descriptive qualitative approach. There were several steps in analyzing this research the find out the kinds of stylistic features are used in Nike sport shoes product slogan and then to explain the message of Nike sport shoes product slogan in stylistic features. The findings of analysis are as follows; stylistic features are used in Nike sport shoes product slogan are morphological is 4 slogans, syntactical and semantic is 27 slogans. The message of Nike sport shoes product slogan in stylistic features are that Nike sport shoes product have better the quality and the ability compared with other sport shoes.
\end{abstract}

Keywords: Stylistic features, Nike sport shoes product slogan.

\section{INTRODUCTION}

Language is a fundamental aspect of human life. To communicate and establish relationship with others, people use language as tool of their communication (Wardhaugh, 1985: 29).

To communicate means to transfer ideas from one person to the others. If people did not have a tool to communicate, people's activities and interactions would be stagnant. It means that language deliver the message that should be understood by other. The communication does not only happen directly, but also it can happen indirectly such as between producer and costumer in industry relation.

Language in advertising is typified by a slogan which is present in every advertisement. It is a representative phrase of the message or a sort of a motto. Angela Goddard in her book The Language of Advertising titles these slogans the hooks which she calls the initial piece of attention seeking verbal language used to draw the reader in (Goddard, 1998: 106). Advertising slogans do not have only 
linguistic attributes but also many various economic features. They must catch our attention, they must be easy to read and easy to remember. Our attention is caught by pictures, illustrations, type of typography, wrong spelling and the use of deviations from normal linguistic structures. Readers can see and remember the message of advertising easily thanks to short simple sentences or slogans, personal and colloquial style, familiar vocabulary, repetitions, alliteration and rhyme. For instance, selling power is best expressed through using imperative mood. It gives a lot of information about the language as well as the society. Advertisement can make, change and consolidate not only economic but also social relations, our personal feelings and group identifications.

Language has a powerful influence over people and their behavior. This is especially true in the fields of marketing and advertising. The choice of language to convey specific messages with the intention of influencing people is very important. When we want to analyze the content of advertising we must clarify its visual and verbal sites to see all aspects of it. Visual content and design in advertising have a very great impact on the consumer, but it is also the language that helps people to identify a product and remember it.
Generally know when an advertisement has caught our attention, and whether it works for us or not, but what exactly is responsible for these effects? It should be decided what techniques are being used to communicate with the audience. Not all advertisements make perfect sense. It is often said that advertising is irrational. The truth is that it always depends on readers how they want to see the concrete slogan, how they understand the process of communication between them and ad makers who send the message covered in advertising slogans. But there is always the crossover between information and persuasion what becomes important.

Advertising has various structures how to attract attention but this study will be interested only in slogans. There are so many slogan products that in advertising one of his slogans in the field of sports. Sports and athletics are extremely predominant phenomena in today's society, as in Sports slogan provide inspiration, identity, and motivation. Then can affect in the ad slogan, usually a lot of sports slogan contained in lifestyle products such as in shoe products, $t$ shirts, etc. An efficient technique to stimulate this identification process is the use an appropriate linguistic register (Goddard, 1998: 26). This concurs with functions of language; they are first of all communicative and informative. Media is the important 
thing to advertise. Effective media to advertise products is online media, because in today's life online media is widely used by people. Online media is a media or communication channel presented online on the internet website.

Based on the background above the research was conducted in analyzing stylistic features of nike sport shoes product slogan on online advertising. Here are some problem discussed in this research:

1. What kinds of stylistic features are used in Nike sport shoes slogans on online advertising?

2. How are the message in the Nike sport shoes slogans on online advertising based on stylistic features?

From the statement of the problem above, the purposes of this research are:

1. To find out the kinds of stylistic features are used in Nike sport shoes product slogans on online advertising.

2. To find out the way of Nike sport shoes product slogans advertising deliver the message through the stylistic features.

\section{THEORITICAL FOUNDATION}

\section{Stylistic}

Stylistic is a branch or general linguistics and sometimes it is called linguo-stylistic which studies the style of the language (Galperin, 1977:9). Linguo-stylistics is an auxiliary discipline which attains its full purpose only when used as a tool to perfect the learner's knowledge of a foreign language or in analyzing a work of literature (Lehtsalu, 1973:13). Cambridge dictionary defines stylistic as the systematic study of style used in language. Oxford English dictionary insert "Stylistics" word firstly in 1822 which has meaning the science of literary style, the study of stylistic features or stylistic devices.

\section{Stylistic Features}

According to Lehtsalu (1973:14), any expressive means may be used in this way for specific artistic purposes and when so employed, it is described as a stylistic devices or stylistic features. The level of language helps in stylistic analysis (Simpson, 2014:5). These levels are related to the branch of language study in linguistics. Simpson calls them as the level of language. The others terms of levels of language in stylistic are stylistic devices or stylistic features. Galperin (1997) called the stylistic features as stylistic devices. Galperin (1977:9) states that the stylistic devices or stylistic features are the special media of language which secure the desirable effect of the utterance.

There are three mainly stylistic features which is used in stylistic analysis:

\section{Morphological Features}


Morphology is the study of internal structure of words. Its etymology is Greek: morph- means 'shape, form', and morphology is the study of form or forms. In stylistic, Morphology are called by level of words and endings (Hickey, 1997:4). The main unit of the morphological level is a morpheme the smallest meaningful unit which can be singled out in a word. Morphology chiefly deals with forms, functions and meanings of affix morphemes.

\section{Transposition of pronouns}

The first, Demonstrative - this, these, that, those may be used to express various shades of emotional meanings, attitudes, from admiration to contempt.

The second, Personal pronouns can express cold official relations, indulgence, arrogance, and sympathy: We are exceedingly charming this evening! (We is used instead of you to express condescending-approving attitude of the speaker to the young girl.

The plural of modesty, in scientific prose we implies the author and his imaginary reader. The author's we, or the plural of modesty, is used with the purpose to identify oneself with the audience or society at large (in order not to mention himself for the reason of modesty but associate himself with his recipients). Example: Now, we come to the conclusion that...
The plural of majesty, we can be used with reference to a single person, the speaker (instead of the pronoun I). It is called the plural of majesty and is used in royal speech: By the Grace of Our Lord, We, Charles the Second...

In literary texts (in prose fiction) you is used to involve the reader into the action, to make him participate in the events, to impart the emotions prevailing in the narration to the reader. Example: You know.

\section{Transposition in nouns}

The first, the use of singular noun instead of an appropriate plural form creates a generalized, elevated effect bordering on symbolization.

The second, the abstract noun normally uncountable used in the plural form hyperbolic plural makes the narration more expressive and brings about aesthetic semantic growth.

\section{Transposition in adjectives}

Transposition of adjectives turns them into nouns to make the utterance more expressive and tangible "The Red and the Black", Isolde the Slender.

The grammatical category of comparison (actually the only grammatical category of the English adjective today) is of great stylistic value in the English language.

The grammatical category of comparison is only typical of quantitative adjectives, and is not found with relative (non-gradable) 
ones. So, when non-gradable adjectives denoting qualities normally incompatible with the idea of degrees of comparison (such as colours, physical states, materials) are used in a comparative or a superlative degree, they acquire an evaluative force and become charged with a strong expressive power: pinker, greener; You cannot be deader than the dead (E. Hemingway).

\section{Verb transpositions}

The verb possesses more grammatical characteristics than any other Part of speech. All deviant usages of tense, voice and aspect forms have strong stylistic connotations and play an important role in creating a metaphorical meaning.

\section{Synonymy of morphemes}

It can be found in the sphere of affixes. Archaic morphemes are met in bookish, high spheres, not in everyday colloquial sublanguage. Example: He hath (has), brethren, thou, thy.

Archaic forms are employed to create historical, realistic, true-to-life background; to impart solemn and elevated effect.

\section{Variation of morphemes}

The usage of archaic, colloquial or low-colloquial forms to create certain stylistic connotations. Grammatical archaisms make the utterance solemn and high-flown: taketh, giveth, hath, couldst, thou, thee, etc.

The usage of contracted forms to create natural character of speech: is not (neutral) - isn't (colloquial), ain't (lowcolloquial).

\section{Syntactical Features}

Syntax is the study of structure. The word "syntax" comes from Greek which means "putting together" or "arrangement" (Yule, 2010: 96). Syntax discusses how sentence or phrase is formed. It relates with the structure that is used in the sentence or phrases. Sentence has various kinds: shortened or extended, complete or incomplete, simple, compound or complex.

\section{Inversion}

According to Lehtsalu (1973:58) inversion (L. inversio 'displacement') is a syntactic stylistic device consisting in the placing of a word or a phrase in an unusual position in a sentence. Inversion in stylistic analysis does not change the meaning of the sentence.

\section{Rhetoric Question}

According to Lehtsalu (1973), Rhetoric question is a question not intended to draw an answer, but used for rhetorical effect. Rhetoric question is the question which does not need the answer, therefore rhetoric question is kind of statement (Luders, 2013:2). it expresses the affirmative of negative statement in interrogative form. 


\section{Parallelism}

According to Lehtsalu (1973), Parallelism is a syntactic stylistic device consisting in a specific similarity of construction of adjacent word groups, equivalent, complementary, or opposite in meaning. Parallelism, consists of phrases or sentences of similar construction and meaning placed side by side, balancing each other (Cuddon, 1999:637). It creates a balanced flow of ideas and can be employed as a tool for persuasion because it uses repetition.

\section{Climax}

Climax is an arrangement, of sentences (or of the homogeneous parts of one sentence) which secures a gradual increase in significance, importance, or emotional tension in the utterance (Galperin, 1977: 211).

\section{Anticlimax}

According to Lehtsalu (1973) Anticlimax or retardation is a stylistic device opposite to climax. It is syntactical stylistic devices consisting in a series of related ideas which is combined with gradual descrease in the degree of some quality or quantity or emotional. The final idea is lower or weaker than the previous.

\section{Repetition}

According to Lehtsalu (1973: 71) Repetition is syntactical stylistic devices consisting in reiteration of the same word or word combination with the object of making the utterance more expressive. Repetition is used to shows the speaker is under the stress of strong emotion (Galperin, 1977: 211).

\section{Antithesis}

According to Lehtsalu (1973) Antithesis is the setting of one clause or a member of a sentence against another to which it is opposed. Antithesis is different with opposition. According to Cuddon (1999: 46) Antithesis is fundamentally, contrasting ideas sharpened by the use of opposite or noticeably different meanings.

\section{Semantic Features}

According to Saeed (2000: 3) Semantics is the study of meaning of words and sentences. Clearly, semantics is a vast subject, and we will only be able to introduce the most important parts of it. 'Meaning', however, is a very vague term. In ordinary English, the word 'meaning' is used to refer to such different things as the idea or intention lying behind a piece of language.

According to Hickey (1997: 4) there are four types of meaning in semantic study; lexical meaning, grammatical meaning, sentence meaning and utterance meaning. Those kinds of meanings prove that a text could be interpreted by some way. Semantics devices in stylistic deal with 
the using of figurative language. It relates with the meaning that contains in words, Phrases or sentences.

\section{Simile}

Simile is a figure of speech in which one thing is likened to another, in such a way as to clarify and enhance an image. Simile uses connective words, such as like, as, such as, as if, and seems. Lehtsalu (1973) defines simile as figure of speech with draw a comparison between two things. The aim of simile is to make the comparison more figurative hence Lehtsalu (1973) said that simile is an imaginative comparison.

\section{Personification}

According to Cuddon (1999: 661) Personification is the impersonation or embodiment of some quality or abstraction, the attribution of human qualities to inanimate objects. Personification is inherent in many languages through the use of gender. Slogan of advertisements can often use personifications when inanimate objects or abstractions are endowed with human qualities to make it more dramatic, interesting and more attractive, because we can better relate to the objects which are personified.

\section{Hyperbole}

$$
\text { Lehtsalu (1973) defines }
$$

hyperbole as transference of meaning based on exaggeration not meant to be taken literally. According to Cuddon (1999: 406) Hyperbole is a figure of speech which contains an exaggeration for emphasis.

\section{Metaphor}

Metaphor is transference of meaning based in the similarity of two notions (Lehtsalu, 1973). Metaphor contributes to the aesthetics of the message and emphasizes the main idea, describing one object in terms of another, usually by means of implicit comparison.

\section{Metonymy}

Cuddon (1999: 510) defines metonymy as a figure of speech in which the name of an attribute or a thing is substituted for the thing itself. Lehtsalu (1973) states that metonymy using a name to refer another thing in associated. Myers (1997) states that metonymy is commonly found in advertisements where the product is associated with some person or surroundings. In stylistic, metonymy has an important role in its function. According to Simpson (2014) metonymy is used as a type of transitivity process which involves the part 'standing for' the whole, and metonymy is important to the technique of caricature. Caricature is a form of metonymic distortion. It means caricature is the frame of abstract imagination. 


\section{Irony}

Irony is a figure of speech in which the literal meaning of a lexical unit is the opposite of that intended (Lehtsalu, 1973: 27).irony is the realization of two opposite meanings, dictionary and contextual meaning. Irony is used to states negative statements in positive one. Irony can be defined as the series of words should be understood in the opposite meaning.

\section{Slogan}

According to Rannu (1998:2) Slogan is the sentence that distinguishes advertisement from both each other and texts. Slogan maybe compared with the headlines of the article. A slogan has to be short, striking, easy to remember, and different from another advertisements. It is usually placed on the top of the advertisement and designed catch the eye of the reader. According to Leech (1972) slogan is a short phrase used by the company in its advertisements to reinforce the identity of the brand. In his opinion, slogans are more powerful than companies' logos and can be easily remembered and recited by people. Also, the scholar states that slogans have to clearly state the main idea of the advertisement, they have to be easy to understand. According to L.Boove and William F. Arens (1986:274) Slogan have two basic purposes. The first is to provide continuity for a campaign. The second is to reduce a key theme or idea the company wants associated with its product or itself to a brief.

\section{METHODOLOGY}

This research uses descriptive qualitative approach in conducting this research. The researcher chooses qualitative research because it can describe characteristics of the data.

According to Maxwell (2004) qualitative research has five essential components:

1. Goals: it answers the question in this study. This research explains a product has a message for people who want to know the product using linguistics.

2. Conceptual Framework: it is about what you think which is going on with the issue, settings, or people you plan to study and the impact of the theories, beliefs, and prior research findings or personal experiences which make the possibilities to guide or inform the research.

3. Research questions: it discusses about what you want to understand by doing this study, what do we not know about the phenomenon under consideration, and what questions will your research attempt to answer, and how are they related to one another.

4. Methods: it is about what will you actually do in this study and the method will be used to collect and analyze the data. 
5. Validity: it relates with the way of ensuring the data collecting, consist of a) address your research questions, b) yield correct and defensible answers to these questions, and c) apply to the larger population or process of interest?

According to Arikunto (1998: 114), the source of data is the subject from which the data are obtained. The data were taken in text form of Nike sport shoes product slogans. The data has been taken from Instagram in official account @nike. There were 27 Nike sport shoes product slogan that had been selected in this research as follows.

This research used purposive sampling technique to obtain data.

\section{RESULT AND DISCUSSION}

\subsection{Kinds of stylistic features that are used in Nike sport shoes slogan on online advertising}

Analysing the stylistic features on Nike sport shoes product slogan using stylistic features theory.

Finding the stylistic features in the text Nike sport shoes product slogan and then classifying the stylistic features in the text Nike shoes product slogan based on the main subject of features.

\section{Morphological Features}

Data 3: Running will never feel the same.

\begin{tabular}{|l|l|}
\hline $\begin{array}{l}\text { Morphological } \\
\text { Features }\end{array}$ & Statement \\
\hline
\end{tabular}

\begin{tabular}{|c|l|}
\hline $\begin{array}{l}\text { Transposition } \\
\text { in adjectives }\end{array}$ & $\begin{array}{l}\text { Running will } \\
\text { never feel the } \\
\text { same }\end{array}$ \\
\hline The text above shows
\end{tabular}

morphological features in Nike sport shoes product slogan. Morphological features is divided into six, transposition in pronouns; transposition in nouns; transposition in adjectives; verb transpositions; Synonymy of morphemes; variation of morphemes. The slogan used transposition in adjectives. There was found a statement used transposition in adjectives and used Transposition of adjectives turns them into nouns. The statement is "Running will never feel the same, the same was showed to feel". Transposition of adjectives turns them into nouns to make the utterance more expressive and tangible. The aim is to make close relationship between the ability of Nike product and the reader.

Data 7: The tougher the run, the better the view.

\begin{tabular}{|l|l|}
\hline $\begin{array}{l}\text { Morphological } \\
\text { Features }\end{array}$ & Statement \\
\hline $\begin{array}{l}\text { Transposition } \\
\text { in adjectives }\end{array}$ & $\begin{array}{l}\text { The tougher } \\
\text { the run, the } \\
\text { better the view }\end{array}$ \\
\hline \multicolumn{2}{|c|}{ The text above shows }
\end{tabular}

morphological features in Nike sport shoes product slogan. The slogan used transposition in adjectives. There was found two statement used transposition in adjectives and used Transposition of adjectives turns them 
into nouns. The first statement is "The tougher the run, the better the view", the tougher was showed to the run. The second statement is "The tougher the run, the better the view", the better was showed to the view. Transposition of adjectives turns them into nouns to make the utterance more expressive and tangible. The aim is to make close relationship between the ability of Nike product and the reader.

Data 22: The legend that still flies. Meet the reinvented Nike Air Pegasus+.

\begin{tabular}{|l|l|}
\hline $\begin{array}{l}\text { Morphological } \\
\text { Features }\end{array}$ & Statement \\
\hline $\begin{array}{l}\text { Transposition } \\
\text { in pronouns }\end{array}$ & $\begin{array}{l}\text { The legend } \\
\text { that still flies. } \\
\text { Meet the } \\
\text { reinvented } \\
\text { Nike Air } \\
\text { Pegasus+ }\end{array}$ \\
\hline The text above shows
\end{tabular}

morphological features in Nike sport shoes product slogan. The slogan used transposition in pronouns. There was found a statement used transposition in pronouns and used demonstrative that. The statement is "The legend that still flies. Meet the reinvented Nike Air Pegasus+". Demonstrative pronoun this was addressed to Nike product. It stated the admiration of Nike product.

Data 24: No one runs a marathon alone. Who's going to take on the windy city Sunday?

\begin{tabular}{|l|l|}
\hline $\begin{array}{l}\text { Morphological } \\
\text { Features }\end{array}$ & Statement \\
\hline $\begin{array}{l}\text { Transposition } \\
\text { in adjectives } \\
\text { and verbs } \\
\text { transposition }\end{array}$ & $\begin{array}{l}\text { No one runs a } \\
\text { marathon } \\
\text { alone Who's } \\
\text { going take on } \\
\text { the windy city } \\
\text { Sunday? }\end{array}$ \\
\hline
\end{tabular}

morphological features in Nike sport shoes product slogan. The slogan used transposition in adjectives and used verb transpositions. The first was found a statement used transposition in adjectives and used Transposition of adjectives turns them into nouns. The statement is "No one runs a marathon alone. Who's going to take on the windy city Sunday?." The windy was showed to going to take. Transposition of adjectives turns them into nouns to make the utterance more expressive and tangible. The aim is to make close relationship between the ability of Nike product and the reader.

The second was found a statement used verbs transposition. The statement is "No one runs a marathon alone. Who's going to take on the windy city Sunday?" it used the use of Present Continuous who's going. It stated the Conviction and the persistence when wearing Nike shoes sport product.

\section{Syntactical Features}

Data 3: Running will never feel the same.

\begin{tabular}{|l|l|}
\hline $\begin{array}{l}\text { Syntactical } \\
\text { Features }\end{array}$ & Statement \\
\hline
\end{tabular}




\begin{tabular}{|l|l|}
\hline Ellipsis & $\begin{array}{l}\text { Running will } \\
\text { never feel the } \\
\text { same }\end{array}$ \\
\hline
\end{tabular}

The text above shows syntactical features in Nike sport shoes product slogan. The slogan used a kinds of syntactical features. That is ellipsis. Ellipsis as a structure is the sentence which does not have complete structure such as no subject or predicate. There was ellipsis in the statement "Running will never feel the same" the statement does not have a subject.

Data 7: The tougher the run, the better the view

\begin{tabular}{|l|l|}
\hline $\begin{array}{l}\text { Syntactical } \\
\text { Features }\end{array}$ & Statement \\
\hline $\begin{array}{l}\text { Parallelism } \\
\text { and Antithesis }\end{array}$ & $\begin{array}{l}\text { The tougher } \\
\text { the run, the } \\
\text { better the view }\end{array}$ \\
\hline
\end{tabular}

The text above shows syntactical features in Nike sport shoes product slogan. The slogan used two kinds of syntactical features, they were parallelism and antithesis. Parallelism is a specific similarity of construction of adjacent word groups, equivalent, complementary, or opposite in meaning, there was found a parallelism statement. The statement is "The tougher the run, the better the view". The word The tougher and the word the better. It implied that those words produce suggestive effect against each other and made the meaning become clear as the utility of the product.

Antithesis is the setting of one clause or a member of a sentence against another to which it is opposed. There was found a antithesis statement, it is "The tougher the run, the better the view". The word The tougher is the opposite of the word the better. It is placed in one statement. It implied that those words against each other made the meaning become clear as the utility of the product.

Data 22: The legend that still flies. Meet the reinvented Nike Air Pegasus+.

\begin{tabular}{|l|l|}
\hline $\begin{array}{l}\text { Syntactical } \\
\text { Features }\end{array}$ & Statement \\
\hline Climax & $\begin{array}{l}\text { The legend } \\
\text { that still flies. } \\
\text { Meet the } \\
\text { reinvented } \\
\text { Nike Air } \\
\text { Pegasus+. }\end{array}$ \\
\hline
\end{tabular}

The text above shows syntactical features in Nike sport shoes product slogan. Syntactical features is divided into eight, Inversion, rhetoric question, parallelism, climax, anti-climax, ellipsis, repetition and antithesis. The slogan used three kinds of syntactical features, they were inversion, climax, and repetition. Climax is a series of related ideas which is combined with gradual increase in the degree of some quality or quantity or emotional. There was found a climax statement, the statement is "The legend that still flies. Meet the reinvented Nike Air Pegasus+." The words flies, and Pegasust are the increase of gradual series of using product.

Data 24: No one runs a marathon alone. Who's going to take on the windy city Sunday? 


\begin{tabular}{|l|l|}
\hline $\begin{array}{l}\text { Syntactical } \\
\text { Features }\end{array}$ & Statement \\
\hline $\begin{array}{l}\text { Rhetoric } \\
\text { Question }\end{array}$ & $\begin{array}{l}\text { No one runs a } \\
\text { marathon } \\
\text { alone Who's } \\
\text { going to take } \\
\text { on the windy } \\
\text { city Sunday? }\end{array}$ \\
\hline
\end{tabular}

The text above shows syntactical features in Nike sport shoes product slogan. Syntactical features is divided into eight, Inversion, rhetoric question, parallelism, climax, anti-climax, ellipsis, repetition and antithesis. The slogan used three kinds of syntactical features, they were inversion, climax, and repetition. Rhetoric question expresses the affirmative or negative statement in interrogative form. There was found a rhetoric question statement, the statement. Is "No one runs a marathon alone? Who's going to take on the windy city Sunday?"

\section{Semantic Features}

Data 3: Running will never feel the same.

\begin{tabular}{|l|l|}
\hline $\begin{array}{l}\text { Semantic } \\
\text { Features }\end{array}$ & Statement \\
\hline Metaphor & $\begin{array}{l}\text { Running will } \\
\text { never feel the } \\
\text { same. }\end{array}$ \\
\hline
\end{tabular}

The text above shows semantic features in Nike sport shoes product slogan. Semantic features is divided into six, simile, personification, hyperbole, metaphor, metonymy, irony. There was found one semantic features, it is Metaphor. There was found a statement used metaphor. The statement is "Running will never feel the same". Metaphor is a comparison of two things in similarity. The statement of metaphor is Running. Based on the statement, Running has figurative meaning which means to place of purpose.

Data 7: The tougher the run, the better the view.

\begin{tabular}{|l|l|}
\hline $\begin{array}{l}\text { Syntactical } \\
\text { Features }\end{array}$ & Statement \\
\hline Hyperbole & $\begin{array}{l}\text { The tougher } \\
\text { the run, the } \\
\text { better the } \\
\text { view. }\end{array}$ \\
\hline
\end{tabular}

The text above shows semantic features in Nike sport shoes product slogan. Semantic features is divided into six, simile, personification, hyperbole, metaphor, metonymy, irony. There was found a statement used hyperbole, the statement is "The tougher the run, the better the view". Hyperbole is an overstatement or exaggeration of an object or phenomenon. The emphasis of hyperbole is in the word tougher and better. The following word tougher showed superlative meaning. The following word better also showed superlative meaning.

Data 22: The legend that still flies. Meet the reinvented Nike Air Pegasus+.

\begin{tabular}{|l|l|}
\hline $\begin{array}{l}\text { Semantic } \\
\text { Features }\end{array}$ & Statement \\
\hline Hyperbole & $\begin{array}{l}\text { The legend } \\
\text { that still flies. } \\
\text { Meet the } \\
\text { reinvented } \\
\text { Nike Air } \\
\text { Pegasus+. }\end{array}$ \\
\hline
\end{tabular}


The text above shows semantic features in Nike sport shoes product slogan. Semantic features is divided into six, simile, personification, hyperbole, metaphor, metonymy, irony. There was found a semantic features, it is hyperbole. There was found a statement used hyperbole, the statement is "The legend that still flies. Meet the reinvented Nike Air Pegasust", Hyperbole is an overstatement or exaggeration of an object or phenomenon.

Data 24: No one runs a marathon alone. Who's going to take on the windy city Sunday?

\begin{tabular}{|l|l|}
\hline $\begin{array}{l}\text { Semantic } \\
\text { Features }\end{array}$ & Statement \\
\hline Metaphor & $\begin{array}{l}\text { No one runs a } \\
\text { marathon } \\
\text { alone Who's } \\
\text { going to take } \\
\text { on the on the } \\
\text { windy city } \\
\text { Sunday? }\end{array}$ \\
\hline
\end{tabular}

The text above shows semantic features in Nike sport shoes product slogan. Semantic features is divided into six, simile, personification, hyperbole, metaphor, metonymy, irony. There was found one semantic features, it is Metaphor. There was found a statement used metaphor. The statement is "No one runs a marathon alone. Who's going to take on the windy city Sunday?". Metaphor is a comparison of two things in similarity. The statement of metaphor is the windy city. Based on the statement, the windy city has figurative meaning which means to place of purpose.

\subsection{Messages in Nike sport shoes product slogan}

Finding the message in the text Nike sport shoes product slogan.

\section{Data 3: Running will never feel the same.}

in this slogan, there is a semantic meaning (metaphor) of the sentence running. Based on the statement above the Nike sport shoes product emphasizes the word the same that Nike sport shoes cannot be compared to other sport shoes because Nike sport shoes are better than other sport shoes. Therefore, the slogan text above conveyed a message to the buyer that Nike sport shoes have great quality and ability compared to other sport shoe products.

In this slogan, the statement running as a predicate but this sentence has not subject. The researcher found ellipsis in the words running will never feel the same. Ellipsis as a structure is the sentence which does not have complete structure such as no subject or predicate.

Data 7: The tougher the run, the better the view.

in this slogan, researcher found the meaning of semantic (hyperbole) in the sentence "The tougher the run, the better the view" The sentence conveyed a message that with heavy activity can make a better appearance, such as the appearance of the product and the appearance of the body. Therefore, the slogan text above explains the meaning to the buyer that Nike sport shoes have great quality of appearance and ability. 
Data 22: The legend that still flies. Meet the reinvented Nike Air Pegasus+.

in this slogan, researcher found the meaning of semantic (metaphor) in the sentence "The legend that still flies. Meet the reinvented Nike Air Pegasus+". The sentence conveyed a message that Nike sport shoes products are still the best products and re-create Nike sport shoes with new versions with better quality. Therefore, the text slogan above explain the meaning to the buyer that Nike sport shoes product have great the quality and the ability.

\section{Data 24: No one runs a marathon} alone. Who's going to take on the windy city Sunday?

in this slogan, researcher found the meaning of semantic (metaphor) in the sentence "No one runs a marathon alone. Who's going to take on the windy city Sunday?" The sentence conveyed a message that Nike sports shoes product invites buyer to exercise and the choice is to use Nike sports shoes. Therefore, the slogan text above explains the meaning to the buyer that Nike sport shoes selected have great quality and ability.

\section{CONCLUSIONS}

The purposes of the research are to find out the kinds of stylistic features are mostly used in Nike sport shoes product slogan and to explain the meaning of Nike sport shoes product slogan in stylistic features. After analysing and discussing this research, the researcher drew some conclusions of the research.

Based on the analysis, there was found that stylistic features are mostly used in Nike sport shoes product slogan are semantic features which consist of simile, personification, hyperbole, metaphor, and metonymy. After that syntactical features which consist of Ellipsis and Climax. Then morphological features which consist of transposition in adjectives and transposition in pronouns. In the semantic features analysis, the researcher found 10 data using that using hyperbole, 8 data using personification, 6 data using metaphor, 3 data using simile and 2 data using metonymy. In the morphological features analysis the researcher found 3 data using transposition in adjectives and 1 data using transposition in pronouns. The last in the syntactical features analysis, the researcher found 8 data using ellipsis, 7 data using climax, 5 data using repetition, 4 data using inversion, 4 data using parallelism, 2 data using antithesis, and 1 data using anti-climax.

There was found that the message of Nike sport shoes product slogan in stylistic features are that Nike sport shoes product have better the quality and the ability compared with other sport shoes. The merger is from 
the whole message of Nike sports shoes product slogan explains the quality and ability of Nike sports shoes and the explanation of the message of the comparison of Nike sport shoes product with other of sport shoes product. 


\section{BIBLIOGRAPHY}

Arikunto, S. (n.d.). Prosedur Penelitian: suatu pendekatan praktek. 2006. Jakarta: PT. Rineka Press.

Bovee, Courland L. \& William F. Arens. 1986. Contempory Advertising 2nd Edition. USA: Home Wood Illinois.

Cohen, D. 1972. Advertising. The USA: John Wiley and Sons, Inc.

Cuddon, J. A. (1999). The Penguin Dictionary of Literary Terms and Literary Theory. London: Penguin Books Ltd.

Dowling, G. R., Kabanoff, B. (1996). Computer-Aided Content Analysis: What Do 240 Advertising Slogans Have in Common? Marketing Letters. Netherlands: Kulwer Academic Publishers, no. 7:1, p. 63-75.

Galperin, I. R. (1977). Stylistics. Moscow: Higher School Publishing House. Retrieved from https://www.academia.edu/15428099/_Galperin_Stylistics_Book_Fi_org

Goddard, A. 1998. The Language of Advertising. Written Texts. New York: Routledge

Godin, S. (2005). Purpurine karvè. Pertvarkykite savo verslą būdami išskirtiniai. Vilnius: Rgrupè

Hickey, Raymond and StanisÓaw Puppel (eds) 1997. Language History and Linguistic Modelling. A Festschrift for Jacek Fisiak on his 60th Birthday. Berlin: Mouton de Gruyter. Retrieved from https://www.unidue.de/ELE/LevelsOfLanguage.pdf

Khader, K. T. (2016). A brief Introduction to Stylistic. Retrieved from a-z-search.com > General Lightings > Fenton Lamps 1980-1982 
Leech, G. (1972). English in Advertising: A Linguistic Study of Advertising in Great Britain (English Language Series). London: Longman.

Lehtsalu, U, Liiv, G, O. Mutt. (1973). An Introduction to English Stylistics. Tartu: Tartu State University. Retrieved from https://dspace.ut.ee/bitstream/handle/10062/51251/lehtsalu_introducti on_1973_ocr.pdf?sequence=1\&isAllowed $=\mathrm{y}$.

Luders, J. (2013). Stylistic devices. Bad Schwartau, Germany: Gymnasium am Muhlenberg. Retrieved from

$\underline{\text { www.jochenenglish.de/abitur/stylistic_devices.pdf }}$

Maxwell, J. A. (2004). Qualitative Research Design. London: Sage publication.

Orakuwe, E, E,. (2015). A Linguistic stylistic analysis of Chimamanda Adichie's. (Thesis of Postgraduate studies, Ahmadu Bello University, Zaria). Retrieved from http://kubanni.abu.edu.ng:8080/jspui/bitstream/123456789/7288/1/A \%20LINGUISTIC\%20STYLISTIC\%20ANALYSIS\%20OF\%20CHIMAMAN DA\%20ADICHIE\%E2\%80\%99S.pdf

Rannu, A. 1998. Advertising Language in Mass Media.

Sachkova, E. V. (2012). Lectures on English Stylistics. Moscow: Moscow State University. Retrieved from library.miit.ru/methodics/28112016/121127.pdf

Saeed, John I. 2000. Semantics. USA: Blackwell Publisher.

Simpson, P. (2004). Stylistic. USA and Canada: Routledge. Retrieved from htttp:/ / www.studfiles.ru/preview/4538348/

Wardhaugh, Ronald. 1986. An Introduction to Sociolinguistics. New York: Brasil Blackwell. 
Yule, George. 2010. The Study of Language. Cambridge: Cambridge University Press.

Zhukovska, V.V. (2010). English Stylistics: Fundamentals of Theory and Practice. Ukraine: The Ministry of Education and Science of Ukraine. Retrieved from http://eprints.zu.edu.ua/12670/1/v.pdf https://www.linkedin.com/pulse/verbal-expression-your-brand-taglines-vs slogans-catherine-chai/ 